\title{
Study on Capital Investment and Marketing of Kiwi Fruit in Ilam, Nepal
}

\section{Aashma Tiwari* and Thaneshwar Bhandari}

Institute of Agriculture and Animal Sciences, Tribhuvan University, Nepal

*Corresponding Author: Aashma Tiwari, Institute of Agriculture and Animal

Sciences, Tribhuvan University, Nepal
Received: May 16, 2020

Published: May 26, 2020

(C) All rights are reserved by Aashma Tiwari and Thaneshwar Bhandari.

\section{Abstract}

The present study was conducted in Sandakpur rural municipality and Ilam municipality of Ilam district between November to December 2018 with a view to determine the socio-economic conditions of kiwi entrepreneurs and their investment appraisal along with major production and marketing constraints. Study collected primary information from 41 kiwi growers, 4 district traders and 2 local marketers by administering semi-structured pre-tested questionnaire. Results revealed that the average cost of production per kg of kiwi was Rs.115. Similarly, estimated average marketing cost was Rs. 38 per kilogram while average processing cost was Rs. 180. Further, kiwi sub-sector alone contributed 20.44 percent of total annual household income. The result showed that the average net present worth, financial rate of return, payback period and break even volume per hectare were Rs.588662, 36\%, 5.01 years and $1789 \mathrm{~kg}$ respectively. Likewise, average benefit cost ratio per hectare was 1.47 with maximum value of 5.29 and minimum value of 0.32. The highest price spread was assessed in case of processing channel of worth Rs.605. The study ranked wild animal attack as major production problem while inadequate storage structure was the most ranked marketing problem. Study suggested bulking kiwi production along with provision of storage structures and processing industries in the study area.

Keywords: Breakeven Volume; Bulking; Investment Appraisal; Marketing Cost; Retailer

\section{Introduction}

Kiwi is a high value crop in Nepal which is mostly cultivated in mid-hills between orange growing region and apple growing region. For a farmer, who has been investing all of his untiring efforts, inputs and hope in subsistence farming and animal husbandry, kiwi farming can serve as a dream catcher for preventing the occurrence of livelihood nightmares in the sleep of poor farmers. Till date, kiwifruit is marketed with tag of "niche product" in the domestic market. There is a huge potentiality for kiwifruit production and promotion, if proper marketing services and systems can be made available to the kiwifruit growers "Productions vs. Marketing of Kiwi Fruits in Nepal" [1].

Kiwifruit, as a high value cash crop, can be a good source of rural income for the marginal farmers of mid-hills who are longing even for their daily basic needs. An article of ICIMOD entitled "Kiwi fruit cultivation" suggests this since it has stated that kiwi farming can improve livelihoods by providing a good source of cash income. [2] Also, kiwi fruit cultivation on sloping land of mid-hills can be a soil-erosion management strategy, which is a sustainable land management practice. It also possesses several health benefits and can also serve as a raw material for many industrial products like jam, jelly, wine, meat tenderizer and so on. By utilizing comparative resource advantage, Nepal can establish herself as a potential producer as well as distributor of kiwifruit across the globe. However, the volume of production, associated produc- tion cost, marketing management, assured quality and flavor and proper storage are the major requisites for kiwi to be competitive in the international market "Kiwi fruit cultivation" [3].

Ilam district carries immense potential for kiwi fruit farming on account of its suitable climatic conditions. It has been declared as kiwi zone by Prime Minister Agriculture Modernization Project (PMAMP) [4] . Based on information of agriculture statistics, Ilam district has been producing 53 metric tonnes of kiwi per hectare. Despite kiwi farming commenced in this district about 12 years ago, it has not been developed to its full potential due to the associated constraints like lack of agriculture programs, capital and labor intensive farming, lack of assured facilities and so on. Besides, lack of information and studies regarding economical benefits and profitability of kiwi enterprise in Nepal has also hindered poor and marginal farmers of Nepal from kiwi farming. Thus, realizing the importance of documentation, assessment of production economics and marketing performance of kiwi, this study is conducted.

\section{Objective of the Study}

This study focuses on assessment of investment appraisal and marketing of kiwi with the objectives: (i) To estimate cost of production, marketing and returns of respondents associated to kiwi farming, (ii) To assess investment appraisal criteria of kiwi entrepreneurs, (iii) To acquaint on price spread in kiwi sell via different marketing channels, (iv) To rank problems in production and 
marketing of kiwi fruit growers. (v) To enumerate possible solution measures for promotion and dissemination strategy ok kiwi farming.

\section{Materials and Methods}

Ilam municipality and Sandakpur rural municipality of Ilam district were purposively selected for this study since all five wards from Sandakpur rural municipality and ward number 1, 2, 3 and 6 from Ilam municipality have been selected as blocks for kiwi zone under PMAMP project in Ilam district. Based on the highest area under kiwi farming and ease for data collection, these two areas were selected. The farmers who have been doing kiwi farming for at least 4 years and who have started gaining economic return from their produce constituted samples for this study. The sample size included 41 kiwi growers, 4 traders, 2 local marketers and 1 key informant. The field survey was conducted between November to December 2018.

\section{Data collection}

Primary data was collected on total cost of production, management practices, total establishment costs, value addition practices from the sample of 41 kiwi growers administering semi-structured pre-tested questionnaire and also by performing key informant interview. Apart from this, data from different market functionaries was collected for the study of marketing cost, price spread and value addition, major marketing problems etc.

\section{Data analysis}

The collected data was coded, tabulated and analyzed with the Microsoft Excel by using simple cost concepts and income measurement. Investment appraisal criteria were employed for the analysis of profitability of kiwi fruit enterprise.

\section{Total production cost}

The total production cost included total fixed costs and total variable costs. Fixed costs consisted of land rent, irrigation cost, training structure preparation cost and sapling cost whereas variable cost consisted of labor cost, manure cost and packaging cost. It was calculated for $1 \mathrm{~kg}$ of kiwi. It was calculated by using following formula:

$\mathrm{C}_{\mathrm{P}}=\mathrm{C}_{\text {land }}+\mathrm{C}_{\text {irri }}+\mathrm{C}_{\text {training }}+\mathrm{C}_{\text {sapling }}+\mathrm{C}_{\text {labor }}+\mathrm{C}_{\text {manure }}+\mathrm{C}_{\text {Harvesting }}$

Where,

$\mathrm{C}_{\mathrm{P}}=$ Cost of production

$\mathrm{C}_{\text {land }}=$ Cost of land rent

$\mathrm{C}_{\text {irri }}=$ Cost of irrigation

$\mathrm{C}_{\text {training }}=$ Cost of training and pruning

$\mathrm{C}_{\text {sapling }}=$ Cost of sapling

$\mathrm{C}_{\text {labor }}=$ Cost of labor

$\mathrm{C}_{\text {manure }}=$ Cost of organic manure

$\mathrm{C}_{\text {harvesting }}=$ Cost of harvesting and packaging

\section{Total marketing cost}

Marketing cost included transportation cost, labor cost, packaging cost, storage cost, load unload cost, communication cost and tax. It was also estimated for $1 \mathrm{~kg}$ of kiwi. It was calculated by using following formula.

$\mathrm{C}_{\mathrm{m}}=\mathrm{C}_{\text {trans }}+\mathrm{C}_{\text {labor }}+\mathrm{C}_{\text {pack }}+\mathrm{C}_{\text {store }}+\mathrm{C}_{\text {load }}+\mathrm{C}_{\text {commu }}+\mathrm{C}_{\text {tax }}$

Where,

$\mathrm{C}_{\mathrm{m}}=$ Cost of marketing

$\mathrm{C}_{\text {trans }}=$ Cost of transportation

$\mathrm{C}_{\text {labor }}=$ Cost of labor

$\mathrm{C}_{\text {pack }}=$ Cost of packaging

$\mathrm{C}_{\text {store }}=$ Cost of storage

$\mathrm{C}_{\text {load }}=$ Cost of load and unload of fruits

$\mathrm{C}_{\text {commu }}=$ Cost of communication

$\mathrm{C}_{\mathrm{tax}}=$ Cost of tax

Net present value (NPV)

Net present value is the difference between present value of cash inflows and present value of cash outflows over a period of time. NPV indicates the present value of net-benefit which is the difference between discounted benefit stream and discounted cost stream. It was calculated as follows:

$N P V=\sum_{t=1}^{n} \frac{B_{t}-C_{t}}{(1+r)^{t}}$

Where,

$\mathrm{Bt}=$ Benefit Stream at time $\mathrm{t}$ of $\mathrm{i}^{\text {th }}$ firm;

$\mathrm{C} t=$ Cost Stream at time $\mathrm{t}$ of $\mathrm{i}^{\mathrm{th}}$ firm.

\section{Financial rate of return (FRR)}

It is the discount rate which just makes the net present worth of the cash flow equal to zero and is calculated through a process of successive approximations until the algebraic sum of annual net incremental benefits will be equal or nearer to zero. It was calculated using following formula:

$$
F R R=L D R+D T D R\left(\frac{N P V \text { at } L D R}{\text { Absolute sum of NPV at } L D R \text { and } U D R}\right)
$$

Where,

LDR = Lower discount rate

$\mathrm{UDR}=$ Upper discount rate

DTDR = Difference between two discount rates

NPV = Net Present Value.

Payback period (PBP)

Payback period is the length of time from the beginning of the investment to the period, before which the net benefits return the cost of capital investment. Thus, it could be taken as the length of 
the time from the beginning of the project until the net value of the incremental production stream reaches the total amount of the capital investment. It was estimated as:

$P B P=$ No of years preceeding final recovery $+\frac{\text { Balance still to be recovered }}{\text { Cash flow during }}$

\section{Benefit-cost ratio (BCR)}

It issimply the ratio of discountedbenefitstream to discountedcoststream and wasestimatedas:

$B C R=\frac{\sum_{t=1}^{T} \frac{B_{t}}{(1+i)^{n}}}{\sum_{t=1}^{T} \frac{C_{t}}{(1+i)^{n}}}$

\section{Breakeven volume}

It is the volume of output at which the producer neither incurslossnorgets profit. It wascalculated as:

Breakeven volume $=\frac{\text { Fixed cost }}{\text { Sales price per unit }- \text { Variable cost per unit }}$

\section{Price spread}

It is the difference between the price paid by consumers and the net price received by the producer for an equivalent quantity of farm produce. It was estimated as:

Price spread $=$ Price paid by consumers(Rs.) - Price received by producers(Rs.)

\section{Problem ranking}

Ranking of production and marketing problem was done by calculating the index of importance for each problem. The problem was ranked according to the value of index of importance in decreasing order. It was calculated by using the following formula: Index of importance $(I)_{i^{\text {th }}}$ firm $=\sum \frac{f_{i} S_{i}}{N}$

Where,

$\mathrm{f}_{\mathrm{i}}$ is the frequency of $\mathrm{i}^{\text {th }}$ index

$\mathrm{S}_{\mathrm{i}}$ is the scale value for $\mathrm{i}^{\text {th }}$ index

$\mathrm{N}=$ Sample size.

\section{Results and Discussion}

Gender and age of respondents

of all the farmers surveyed in the cluster, there were 31 male farmers and 10 female farmers. The maximum age, minimum age and average age of respondents were 72, 25 and 50 respectively.

\section{Land holding size}

The average land holding of the sampled farmers was 1.43 ha which was greater than the national average land holding of 0.68 ha [5]. Of the total area, average kiwi area allocated by the farmers was 0.30 ha which consisted of about $20.42 \%$ of the total land holding and had irrigation facilities for total allocated area for kiwi.

\section{Education status of household head}

In figure 1, it was found that the educational level of the farmers surveyed in the cluster is fairly good and only 7.5 percent of them were illiterate. While about 40 percent farmers had primary

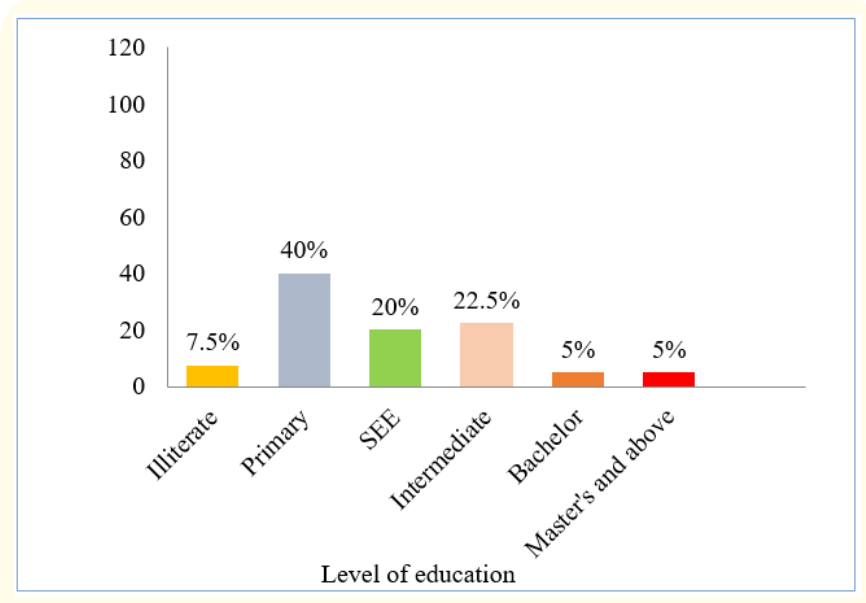

Figure 1: Educational status of household head. Source: Field survey, 2018.

education, rest had better formal educational qualifications. About 20 percent of farmers were educated to SEE level and 22.5 percent to intermediate level. Among the sampled farmers,5 percent had bachelor degree and 5 percent had master's degree.

\section{Age distribution of family members}

The family composition was divided into three age groups: less than 15 years, between 15 to 59 years and greater than 60 years. The people between the age groups of 15 to 59 years were taken as economically active population and those of age groups less than 15 years and greater than 59 years were taken as economically inactive or dependent population. Figure 2 depicts that majority of the family members: 66 percent belonged to the age group of 15-59 years. It meant that majority of family members were economically active.

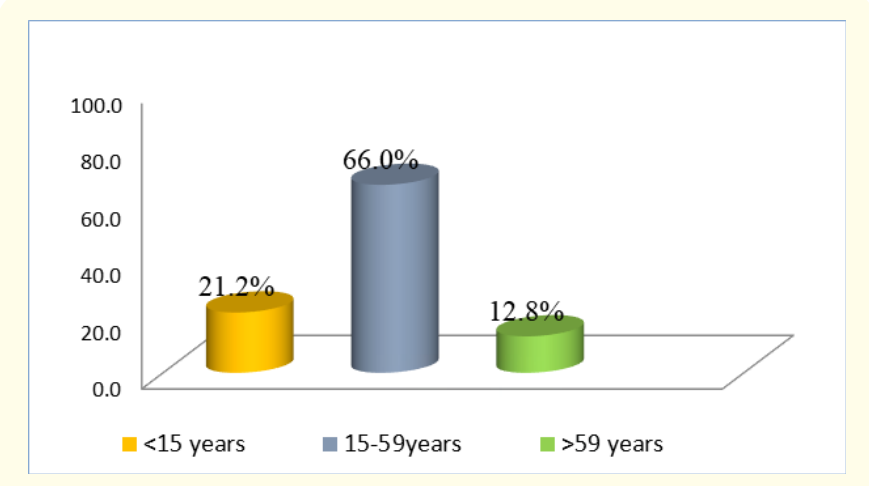

Figure 2: Age distribution of family members. Source: Field survey, 2018.

\section{Kiwi trees and varieties}

The maximum, minimum and average numbers of kiwi trees found in the survey area were 650, 6 and 74 respectively. The average number of productive trees was 49 . Similarly, among 41 households, 46 percent had only green kiwi varieties, 10 percent had only red kiwi varieties and 44 percent had both red and green kiwi 
varieties. The source of the varieties were local nurseries, ICIMOD's botanical garden etc. The common kiwi varieties in the households were Hayward, Bruno, Monty, Abotto, Allison, Red-Early etc. Kiwi trees were planted @ 12 plants/ropaniof land.

\section{Intercultural operations of kiwi growers}

Among 41 sampled farmers, 95 percent had conventional staking, 2.5 percent had iron-staking and 2.5 percent had both staking system. Similarly, 37 percent had bee-keeping practices and 63 percent had no bee-keeping practices. Also, 37 percent farmers had shade trees around kiwi orchard whereas 63 percent had no such practices. Farmers used FYM for manuring on yearly basis after harvesting in old plants and during December in new plants. No chemical fertilizers were used for manuring in the study area. The maximum FYM applied per plant was 4 doko, minimum 1 doko and average 2 doko. Farmers practiced training and pruning in winter after the harvesting of fruits in the month of December to January. The labor required for training and pruning was about 10 trees per person in one day.

\section{Change in land holding of kiwi}

It was learnt during the field interactions that many farmers have established new orchards in the last couple of years signifying a rapid shift towards kiwi cultivation from cardamom farming in the study area. The result showed that 66 percent of sampled farmers had increased their land size of kiwi as compared to the beginning year.

\section{Annual household income}

From table 1, the share of kiwi, livestock, tea and cardamom and off-farm activities were 20.4 percent, 24.1 percent, 28.6 percent and 26.8 percent respectively. Tea and cardamom accounted for the maximum share in total household income whereas kiwi had the minimum one. Still kiwi sub-sector alone contributed for about 20.4 percent of the total annual household income having a great potentiality for commercialization.

\begin{tabular}{|l|c|c|}
\hline & Rs. & $\begin{array}{c}\text { Percent share in } \\
\text { total income (\%) }\end{array}$ \\
\hline Total annual kiwi income & 5482000 & 20.4 \\
\hline $\begin{array}{l}\text { Total annual livestock } \\
\text { income }\end{array}$ & 6475600 & 24.1 \\
\hline $\begin{array}{l}\text { Total annual tea and } \\
\text { cardamom income }\end{array}$ & 7675000 & 28.6 \\
\hline $\begin{array}{l}\text { Total annual off-farm } \\
\text { income }\end{array}$ & 7186000 & 26.8 \\
\hline $\begin{array}{l}\text { Total annual household } \\
\text { income }\end{array}$ & 26818600 & 100 \\
\hline
\end{tabular}

Table 1: Components of total annual household income. Source: Field survey, 2018.

\section{Elements of cost of production}

The total cost of production was estimated for $1 \mathrm{~kg}$ of kiwi. It included fixed costs and variable costs. Fixed costs included Land rent, irrigation cost, training structure preparation cost and sapling cost whereas variable cost included labor cost, manure cost and packaging cost. Figure 3 depicts that the labor cost accounted for the highest variable cost in total production cost with the share of 25 percent followed by manure cost(21 percent) and packaging cost(2 percent). Similarly, the highest fixed cost was of sapling cost with the share of 22 percent in total production cost followed by irrigation cost(14 percent), training structure preparation $\operatorname{cost}(13$ percent) and land rent cost ( 3 percent). The average production cost for $1 \mathrm{~kg}$ of kiwi was Rs. 115 which consisted of labor cost of Rs. 28.75, sapling cost of Rs. 25.4, manure cost of Rs.25, irrigation cost of Rs. 16, training structure preparation cost of Rs. 15, land rent cost of Rs.3 and packaging cost of Rs.2.

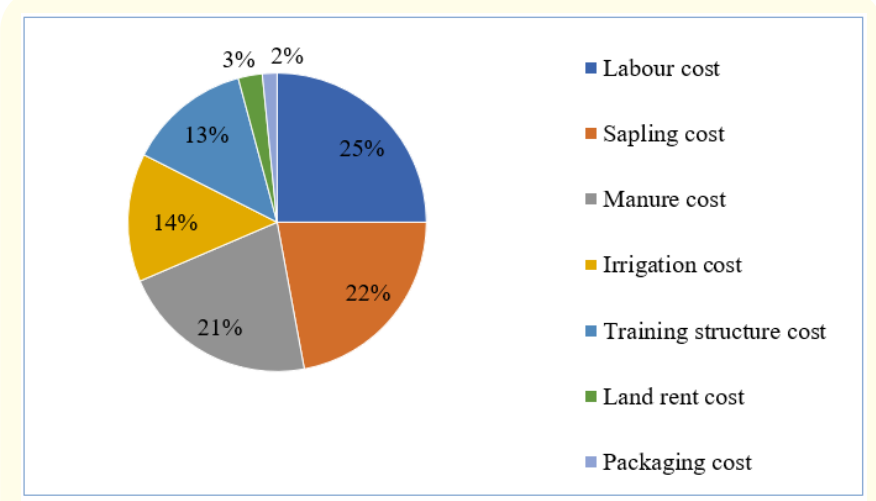

Figure 3: Elements of cost of production estimated for $1 \mathrm{~kg}$ of kiwi. Source: Field survey, 2018.

\section{Elements of cost of marketing}

In figure 4, transport cost accounted for the highest marketing cost of about Rs.12 (29\%) followed by labor cost of Rs. 7.6 (25\%), packaging cost of Rs.7 (19\%), storage cost of Rs.4(10\%), load unload cost of Rs.3.6 (9\%), communication cost of Rs.2 (5\%) and tax of Rs.1.2 (3\%). It was supported by a study made by Mali et al in banana of Jalgaon district which showed that high transportation cost as one of the marketing problem [6]. The average marketing cost per kg of kiwi was Rs. 38 in the marketing channel producer to wholesaler.

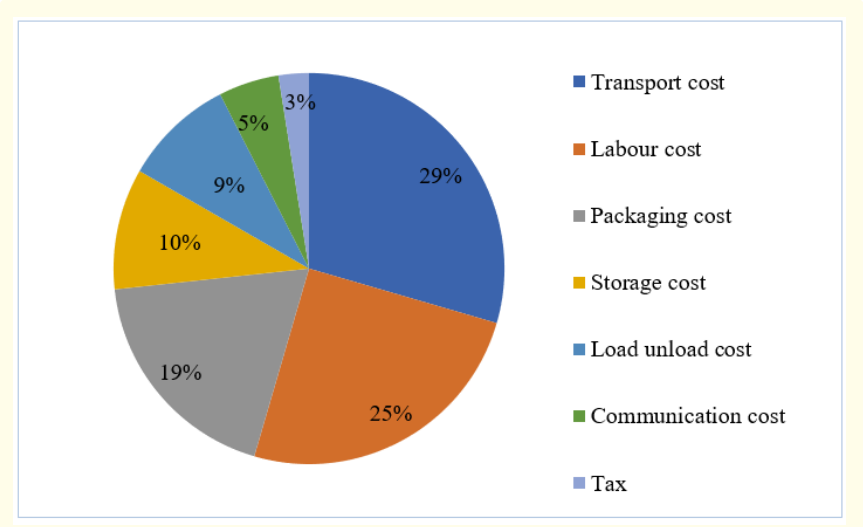

Figure 4: Elements of cost of marketing estimated for $1 \mathrm{~kg}$ of kiwi.[Source: Field survey, 2018]. 


\section{Net present value}

Table 2 shows that the maximum, minimum and average netpresent value per hectare were Rs. 4103205, Rs. 157 and Rs.588662 respectively. The minimum NPV belonged to the farmer who was in just $6^{\text {th }}$ year of cultivation and the maximum NPV was of the farmer who had been doing kiwi farming for 10 years long. Since average NPV is positive, we can say that kiwi farming is profitable in the study area. Also the NPV in the early years, upto 5 years has been found to be negative. The number of kiwi growers having negative NPV for first, second, third, fourth and fifth year were 41, 40, 21, 6 and 2 respectively. It is because the costs incurred in the early years of establishment is greater than the income generated during those years due to the fact that being a perennial tree, kiwi starts bearing fruits after 2 to 3 years of planting and it takes about 5 or more years for a kiwi tree to undergo commercial production. The average fruiting duration was 3 years and the annual average yield was $34 \mathrm{~kg} /$ tree.

\begin{tabular}{|c|c|}
\hline NPV & Value (Rs.) \\
\hline Maximum & 4103205 \\
\hline Minimum & 157 \\
\hline Average & 588662 \\
\hline
\end{tabular}

Table 2: Maximum, minimum and average net present value of surveyed farmers.

Source: Field survey, 2018.

\section{Financial rate of return}

From table 3, the average financial rate of return (FRR) was 36\% with the maximum value of $161 \%$ and minimum of $10 \%$. It means that at the interest rate of $36 \%$ the net-present value becomes zero which means benefits generated is equal to costs incurred. The maximum FRR belonged to the farmers having older orchard(total 10 years of cultivation) and the minimum FRR belonged to the farmer in the $6^{\text {th }}$ year of cultivation. Since FRR is greater than the opportunity cost of capital (12\%), we can say that kiwi farming is profitable in the study area.

\begin{tabular}{|c|c|}
\hline FRR & Value (\%) \\
\hline Maximum & 161 \\
\hline Minimum & 10 \\
\hline Average & 36 \\
\hline
\end{tabular}

Table 3: Maximum, minimum and financial rate of return of surveyed farmers.

Source: Field survey, 2018.

\section{Payback period (PBP)}

Table 4 shows that the average payback period was 5 years with maximum value of 9.30 and minimum value of 1.63 years. The PBP is \% \% years means that after 5 years of orchard establishment, the farm would be able to recover its initial investment.

\begin{tabular}{|c|c|}
\hline PBP & Value (Years) \\
\hline Maximum & 9.30 \\
\hline Minimum & 1.63 \\
\hline Average & 5.01 \\
\hline
\end{tabular}

Table 4: Maximum, minimum and average payback period of surveyed farmers.

Source: Field survey, 2018.

\section{Benefit cost ratio (BCR)}

From table 5, the average benefit-cost ratio per hectare was 1.47 with maximum value of 5.29 and minimum value of 0.32 . Similar results were obtained in a study made by Maniratna Aryal in 2016 [7] in which the $\mathrm{BC}$ ratio of fruits ranged from 1 to 5 . The $\mathrm{BC}$ ratio is greater than one. It means that the selected entrepreneurs were getting profit from kiwi business. The reasons behind the fluctuation of $\mathrm{BC}$ ratio among the surveyed farmers were different years of cultivation, varieties, management practices, different marketing channels, quality and grades etc.

\begin{tabular}{|c|c|}
\hline BCR & Value \\
\hline Maximum & 5.29 \\
\hline Minimum & 0.32 \\
\hline Average & 1.47 \\
\hline
\end{tabular}

Table 5: Maximum, minimum and average benefit-cost ratio of surveyed farmers.

Source: Field survey, 2018.

Analysis of value addition and price build-up from farmer to intermediaries to consumer

With the help of costing analysis done above, the price build up for kiwi was calculated for the most prevalent channel. A typical cost buildup for $1 \mathrm{~kg}$ of kiwi is indicated in figure 5 .

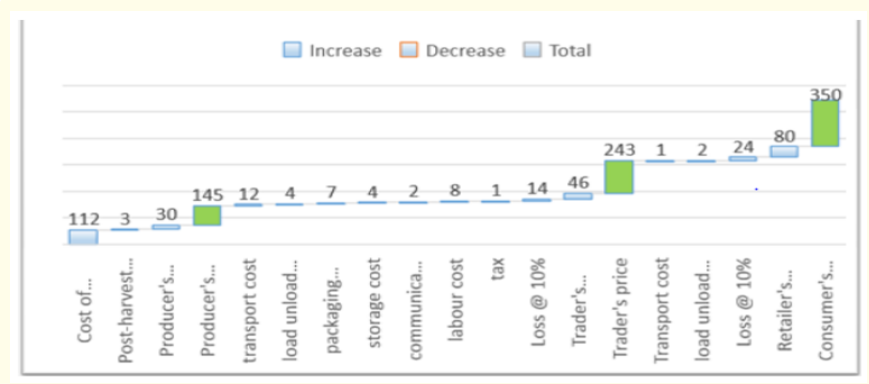

Figure 5: Price buildup for $1 \mathrm{~kg}$ of kiwi. [Source: Field survey, 2018].

As per figure 5, the farmer's share in the final rupee spent by consumer estimated for the most prevalent marketing channel (Producer-wholesaler-retailer-consumer)was 41 percent whereas, the share of intermediaries was about 36 percent. It was also indic- 
ative from the analysis that while the cost of kiwi production was fairly low and majority of the cost (i.e. about 23\%) was involved in marketing, handling and transportation and post harvest losses. The average post harvest loss was about Rs.38 per kg kiwi. Similar results were obtained in a study made by CGS national institute of agricultural marketing in the value chain analysis of kiwi in Arunachal Province of India. [8] Aforementioned, a significant loss in the value chain was due to high perishable nature of the crop and improper packaging. Due to lack of facility for cold stores, refrigerated trucks etc. the wastages became higher. With right packaging and integrated cold chain infrastructure, the current losses may be reduced largely for better value realization at each level.
Price spread and producer's share in marketing channels

Table 6 depicts that the highest price spread was in Channel IV of worth Rs. 605 followed by channel III (Rs.205) and channel II (Rs.155). Channel I had no price spread since there was no involvement of intermediaries between producer and consumer level. Similarly, the intermediaries share was highest in channel IV followed by channel III and channel II. Producer's share over retailer's payment was maximum in Channel I with share of $100 \%$ followed by channel II (48\%), channel III(41\%) and channel IV(19\%) respectively. The maximum price spread was in channel IV: at the processor level because $1 \mathrm{~kg}$ of kiwi of worth Rs. 145 is processed into two bottles of jam of worth Rs. 375 each.

\begin{tabular}{|l|c|c|c|c|}
\hline & $\begin{array}{c}\text { Channel I (Producer- } \\
\text { Consumer) }\end{array}$ & $\begin{array}{c}\text { Channel II (Producer- } \\
\text { Wholesaler-Consumer) }\end{array}$ & $\begin{array}{c}\text { Channel III (Producer-Whole- } \\
\text { saler-Retailer-Consumer) }\end{array}$ & $\begin{array}{l}\text { Channel IV (Producer- } \\
\text { Processor-Consumer) }\end{array}$ \\
\hline $\begin{array}{l}\text { Price paid by } \\
\text { consumers (Rs.) }\end{array}$ & 200 & 300 & 350 & 750 \\
\hline $\begin{array}{l}\text { Price received by } \\
\text { producers (Rs.) }\end{array}$ & 200 & 145 & 145 & 145 \\
\hline Price spread (Rs.) & 0 & 155 & 205 & 605 \\
\hline $\begin{array}{l}\text { Intermediaries share } \\
(\%)\end{array}$ & 0 & $52 \%$ & $59 \%$ & $81 \%$ \\
\hline Producer's share (\%) & 100 & $48 \%$ & $41 \%$ & $19 \%$ \\
\hline
\end{tabular}

Table 6: Price spread, producer's share and intermediaries share in different marketing channels. Source: Field survey, 2018.

\section{Ranking of production problems}

Table 7 shows that the most-ranked production problem of kiwi growers was wild attack with index value 0.86 followed by training and pruning, credit unavailabiity, selling arrangement and low productivity. The study area lacked proper fencing structures around the orchard which is the main reason behind prominent wild attack.

\section{Ranking of marketing problems}

Table 8 depicts that the most-ranked marketing problem of marketers and traders was lack of storage structures for kiwi with index value of 0.95 followed by low selling price, weight loss, transport loss and poor handling. The result is supported by the findings of the study made by Kerutagi,et al.[9] on constrainst of marketing of sapota in which lack of storage structures was ranked as the major marketing problem with a value of $94.44 \%$. Kiwi requires controlled atmosphere storage or cold storage facilities in which it can be stored fresh upto 5-6 months. But lack of appropriate cold

\begin{tabular}{|l|c|c|}
\hline \multicolumn{1}{|c|}{ Problems } & Index value & Rank \\
\hline Wild attack & 0.86 & I \\
\hline Training and pruning & 0.63 & II \\
\hline Credit unavailability & 0.53 & III \\
\hline Selling arrangement & 0.50 & IV \\
\hline Low productivity & 0.46 & V \\
\hline
\end{tabular}

Table 7: Ranking of production problems. Source: Field survey, 2018.

\begin{tabular}{|l|c|c|}
\hline \multicolumn{1}{|c|}{ Problems } & Index value & Rank \\
\hline Lack of storage & 0.95 & I \\
\hline Low selling price & 0.7 & II \\
\hline Weight loss & 0.55 & III \\
\hline Transport loss & 0.5 & IV \\
\hline Poor handling & 0.3 & V \\
\hline
\end{tabular}

Table 8: Ranking of marketing problems. Source: Field survey, 2018.

storage structures in the study area resulted for high post-harvest losses and quality losses in kiwi.

\section{Conclusion}

Kiwifruit is a prioritized sector of Prime Minister Agricultural Modernization Project (PMAMP) in Nepal. Additionally, Ilam is the potential production area of kiwi on account of its favorable climatic condition and also due to the fact that Ilam is declared as kiwi zone by government under PMAMP project.

From this study, higher BC ratio, positive NPV and IRR greater than opportunity cost of capital indicated that the fruit appears to be highly profitable and remunerative enterprise in Ilam district of Nepal. Additionally, kiwi cultivation was found to be having prominent contribution to household income and thus can be a suitable option for uplifting the socio-economic status of kiwi farmers. The marketing system, however, still needs to be more developed with 
the provision of least possible intermediaries between producer and consumer in order to decrease the value of price spread. It is unfortunate that farmers are still away from the reasonable price of their product. Kiwi entrepreneurs can earn more profit if they start to perform value addition by processing in future. This business will provide more employment opportunities by the establishment of processing industries in future.

Speaking of problems, wild attack and lack of storage facility were found to be the major production problem of kiwi growers and marketing problems of kiwi traders respectively. Kiwi fruits are perishable in nature but we can extend their life up to six months after harvesting by the use of controlled atmosphere storage, cold store and other advanced techniques which help to generate higher price than the seasonal price. This means, the $\mathrm{B} / \mathrm{C}$ ratio will be higher than the calculated one if focused on farm gate price in this study. For getting desired benefits, it is better to practice group-marketing or going through producers group or associations. The farmers should follow better management practices like proper pruning and training by trained ones, timely irrigation, using proper dose of manure, shading, bee-keeping practices, plant protection, proper harvesting and so on in order to get higher benefits from kiwi cultivation.

\section{Recommendations}

Based on the findings of research, the following recommendations are made for making the kiwi enterprise more profitable:

- The investment appraisals were found very satisfactory in this study. Based on this study, Kiwifruit is the best potential fruit in temperate zone. Study suggests replication of the techniques adopted by Kiwi farmers of Ilam in other potential areas of Nepal.

- $\quad$ Farmers are suggested to establish farmer's cooperative of Kiwi under the collaboration of local municipalities in order to enable group-marketing of kiwi fruits, saplings and seedlings in the study area in order to increase farm gate price, increase farmer's share and operation efficiency in sale.

- $\quad$ Researcher suggests local municipalities of Ilam and Agriculture Knowledge Centre Ilam to empower and encourage kiwi entrepreneurs by the provision of awareness on nutritional importance of kiwifruit as well as by making suitable arrangements for local marketing and distribution system of kiwi.

- $\quad$ Concerned growers are suggested to follow scientific management practices required for kiwi cultivation.

- $\quad$ Agriculture Knowledge Centre Ilam, local agrovet shops and input suppliers are suggested timely supply of quality inputs and technology as well as market information to the farmers.
- Provincial government 1 and central government intervention is necessary to stabilize price and supply of quality inputs in time. Storage facilities, training and demonstration on improved technology in kiwi cultivation should be provided to the farmers.

- Provincial government 1 facilitation is necessary for kiwi farmers by the provision of subsidy on inputs and establishment of processing industries which would result in the value addition and famers getting appropriate of their products.

- Ilam Chamber of Commerce is suggested to focus on production of sufficient seedling as per the demand of farmers and its supply on time of plantation and export provision directly to adjoining India and other market outlet.

- Insurance Board of Nepal and Ministry of Agriculture and Livestock Development are suggested to bring kiwifruit insurance policy for the encouragement of kiwi growers and traders.

- $\quad$ Researcher suggests further study in other areas like value chain study of kiwifruit, sensitivity analysis of kiwifruit enterprise which would help the researcher to become clear on the profitability of kiwi enterprise.

- Since Ilam is near to the border of India, it would be better if the necessary arrangements can be made for direct export of the kiwifruit via Pashupatinagar and shortest marketing

\section{Bibliography}

1. Shakya G. "Production vs. marketing of kiwi fruits in Nepal" (2018).

2. International Centre for Integrated Mountain Development (2012).

3. KC S. NPAC Pvt. Ltd hopes to change Nepal's kiwifruit industry (2017).

4. Bhattarai B. "Project designates Ilam as kiwi development zone" (2018).

5. Central Bureau of Statistics (2011).

6. Sarode SC. "Economics of banana marketing in Jalgaon district: An analysis across alternative channels". African Journal of Marketing Management 1.5 (2009): 128-132.

7. Aryal M and NB Bhandari. "Average cost of production and gross profit of fruit farming in Nepal” (2015).

8. Mani G., et al. "Kiwi value chain in Arunachal Pradesh: issues and prospects". Agricultural Economics Research Review 31.1 (2018):347-3196. 
9. Kerutagi MG., et al. "Marketing of Sapota in Northern Karnataka”. Indian Journal of Agricultural Marketing 23.2 (2009): 57-63.

\section{Assets from publication with us}

- Prompt Acknowledgement after receiving the article

- Thorough Double blinded peer review

- Rapid Publication

- Issue of Publication Certificate

- High visibility of your Published work

Website: www.actascientific.com/

Submit Article: www.actascientific.com/submission.php Email us: editor@actascientific.com

Contact us: +919182824667 